\title{
Mergers and Acquisitions and Trade Integration: A Spatial and Temporal Study of India
}

\author{
Balachandran $\mathrm{BV}^{1 *}$ and Lavanya $\mathrm{CNM}^{2}$ \\ ${ }^{1}$ Department of Accounting and Information Management, Northwestern University, Illinois, USA \\ ${ }^{2}$ Department of Management, Great Lakes Institute of Management, India
}

\begin{abstract}
The objective of this study is to analyze the nature and implications of changes in the number of Mergers and Acquisitions bids pertaining to Indo-US and Indo-Europe cross-border deals, on a pre-and post-sub-prime crisis basis. These numbers are correlated with $Y_{i j}$ (gamma-ness of trade). There was a decline in $Y_{i j}$ in 2009 , for the said geographies, reflecting the impact of sub-prime crisis. The bids increased in the post-crisis period only for Indo-US Mergers \& Acquisitions, where India was the target. The F value is solid when the acquirer is India and the target is either USA or Europe.
\end{abstract}

Keywords: Emerging markets; Trade; Greenfield investment; Bankruptcy law

\section{Introduction}

The global economic milieu since the turn of the century has been one of liberalization and financial deregulation. The year 200405 is co-terminus with the discernible liberal phase in Indian policy regime towards outbound Foreign Direct Investment (FDI) and the concomitant boom in foreign acquisitions by Indian firms. The borders across geographies are increasingly becoming blurred, especially in this Internet era (post-1995), notwithstanding the differences along cultural, administrative, geographic and economic dimensions. This is attributable to the developments in Information, Communication and Technology (ICT) sector.

\section{Aim of the Paper}

The aim of the study is to analyze the number of Mergers and Acquisition (M \& A) bids, with respect to geographies such as USA and Europe. This is carried out, having India as the base as it is a buoyant emerging economy. Later, this paper seeks to give a description of the changes in the number of those bids and ramifications thereof, in the time span of 2004-2012, with the sub-prime crisis in 2008 acting as a mid-point. Further, the differences in the bids prior to and subsequent to the global financial meltdown are studied in this paper. These bids are then mapped with a measure called the gamma-ness of trade, in order to ascertain the magnitude of trade integration among the said geographies. Thus, this paper seeks to contribute to the repository of literature relating to Emerging Market Multinationals, with specific reference to India. The 'period effects' are sought to be captured, wherein the changes in global conditions alter the costs and associated risks of internationalization.

There has been heightened activity in M \& A space and the inorganic growth route has taken precedence over the organic one in the recent past. The $\mathrm{M} \& \mathrm{~A}$ at a global level registered a rise from $\$ 550$ billion in 1990 to $\$ 3.8$ trillion in 2015 - it surpasses the previous record of pre-crisis level. However, there was a decline in the M \& A activity in India, which stood at around $\$ 20$ billion, down from about $\$ 33$ billion in 2014.

The temporal milestones in the journey of M \& A activity are given as under:

- 1991-92: This year is a watershed in the Indian economy as it embraced Liberalization-Privatization-Globalization (LPG).
The Licence Permit Raj or licence was abolished (barring a few industries) and there was impetus to private domestic and foreign capital.

- 1995-96: This year saw the spread of Internet, which metamorphosed life in general and business in particular. The Internet as well as Intranet tornadoes brought about a revolution in peoples' lives. The tacit corporate knowledge got codified, mainly due to the developments in the IT space and was made explicit through Externalization. Further, the process of Combination was made possible by the spread of Information Technology. Figure 1 further elucidates this. Furthermore, there was a spurt in offshoring (cross-border) and outsourcing (domestic), thanks to the Internet revolution [1]. The adaptation and arbitrage (part of the AAA Framework of Ghemawat)-driven strategies of various software companies played a pivotal role in this process.

- 1999-2000: The $\mathrm{Y} 2 \mathrm{~K}$ phenomenon gave birth to many dotcom companies.

- 2004-05: There was the discernible liberal phase of Indian policy regime towards outbound FDI and therefore, the cross-border M \& As started increasing significantly.

- 2008-09: The economic meltdown in the form of sub-prime crisis unfolded in this year.

\section{Literature Review}

Bertrand et al. [2] examined the reactions of domestic and foreign firms with differing technologies for varied phases of economic integration. They modeled the impact of gradual trade liberalization which, inter alia, includes cross-border M \& A strategy. The 'phi-ness of trade', which reflects the sectoral bilateral trade integration between two markets was used for assessing market access. They studied the

*Corresponding author: Balachandran BV, Department of Accounting and Information Management, Northwestern University, Illinois, USA, Tel: +1-8475648698; E-mail: b-bala@kellogg.northwestern.edu

Received March 25, 2016; Accepted May 13, 2016; Published May 17, 2016

Citation: Balachandran BV, Lavanya CNM (2016) Mergers and Acquisitions and Trade Integration: A Spatial and Temporal Study of India. J Glob Econ 4: 192. doi:10.4172/23754389.1000192

Copyright: ( 2016 Balachandran BV, et al. This is an open-access article distributed under the terms of the Creative Commons Attribution License, which permits unrestricted use, distribution, and reproduction in any medium, provided the original author and source are credited. 


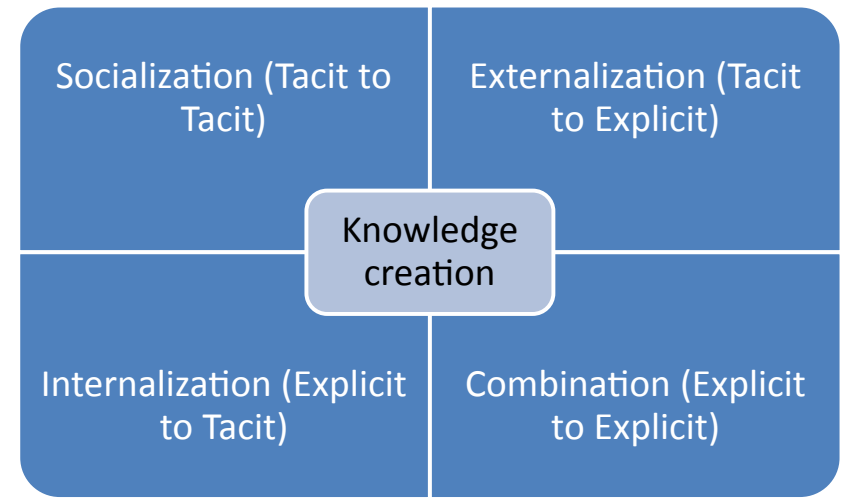

Figure 1: Four modes of knowledge creation (Adapted from Ikujiro Nonaka's work).

effect of trade liberalization on $M \& A$ incentives, depending on the technological gap.

The work of Ray et al. [3] showed the lack of influence of ethnic and cultural relations between home and host countries in the initial outbound ventures by Indian companies in the post-liberalization era. The companies in advanced OECD countries are the prime targets of outbound FDI from India.

Li et al. [4] studied the manner in which inward FDI influences Emerging Multinational Enterprises' (EMNEs) knowledge-seeking outward FDI. They showed that, notwithstanding the knowledge spillovers from inward FDI, it is an imperfect substitute of, and not a replacement for, outward FDI. They applied a semiparametric Cox model to estimate the hazard of investment in a host country.

The study of Ramamurti [5] focused on the issue that MNEs in emerging and developed markets are in different stages of internationalization. He pointed out that the EMNEs invalidate the canons of 'Stages model of internationalization' (Johanson and Vahlne) and the 'Product Cycle Hypothesis' (Vernon). The country of origin apart, the contextual variables such as the global environment for internationalization, MNE's stage of evolution and the industry in which it operates, are the determinants of EMNEs' international strategy.

Singal et al. [6] developed the 'Capabilities-then-size' framework to denote the strategic path of EMNCs, with specific reference to India. They indicated that Indian MNCs from pharma and auto sectors moved from 'constrained dominance' to 'dominance', whereas IT firms moved from 'susceptibles' to 'dominance, which was achieved via their global footprint.

Agnihotri [7] found that the acquisition decision of a firm is determined significantly by earnings volatility and business group affiliation in India. A sample of 360 firms, spanning three fast-growing sectors, was chosen for the period 2004-10. There is an inverted ' $U$ ' curvilinear relationship between earnings volatility and firm's inclination for acquisition. The business group affiliation plays the role of a moderator with reference to volatility in earnings and strategy of acquisition.

Contractor [8] identified the sources of competitive strength of Emerging Market Multinationals (EMMs), the strategy archetypes that EMMs seemingly fit into and the link between the behavioral attributes of top management, cultural backdrop of EMMs and their success. Though the EMM's are fraught with the double jeopardy of 'liabilities of foreignness' (Eden and Miller) and the liabilities associated with the home base in an emerging economy, many of them outpaced the industry averages.

To sum it up, the literature surveyed portrays the myriad phases of economic integration, phi-ness of trade; the effect of inward FDI on outward FDI by EMNEs; differing stages of internationalization of MNEs in emerging and developed markets; sectoral instances of framework that depict strategic path of EMNCs and the competitive strength of EMMs. Thus, there is a growing body of literature pertaining to emerging market economies and MNCs therein.

This paper seeks to fill the gap in existing research relating to India, USA and Europe being hub and spokes of one another. In other words, one region is the acquirer, with the other areas being targets and viceversa. Scenario analysis of the time period before and after the global meltdown in 2008 is explored in this paper.

\section{Methodology}

\section{Gamma-ness of trade}

A measure named Yij (gamma-ness of trade), constructed by the authors, was employed in this study. It is a variant of $\emptyset_{\mathrm{ij}}$ (phi-ness of trade), used by Bertrand et al. [2]. Yij captures the extent of market integration between two economies.

Yij $\left.=\left\{\left(\mathrm{mij}^{\star} \mathrm{mji}\right) / \mathrm{mii}^{\star} \mathrm{mjj}\right)\right\}^{\wedge} 0.5$

Where mij represents the imports of $\mathrm{i}$ from $\mathrm{j}$ and vice-versa for mji.

mii and mij denote local sales (Gross National Income (GNI) on Purchasing Power Parity (PPP) basis, minus exports in an economy i or $\mathrm{j}$ \}.

Yij lies between 0 and 1 and the closer it is to 1 , the more markets are integrated. It differs from $\emptyset_{\mathrm{ij}}$ in the following ways:

- Trade in products/merchandise and not total trade was considered in the calculation of Yij.

- Trade in the economies as a whole was taken into account in Yij, unlike $\emptyset \mathrm{ij}$, where the sectoral trade was taken.

GNI on PPP basis, sourced from the World Bank data, was used in part-calculation of the denominator. It has been used as a proxy for the total production [9-13].

United Kingdom was chosen to be the representative of Europe for calculation of Yij.

\section{Research questions (RQ), hypotheses $(\mathrm{H})$ and variables $(\mathrm{V})$ :}

The data relating to the number of cross-border $\mathrm{M} \& \mathrm{~A}$ bids for the time period January 2004 to December 2012, along with the respective Base Equity Value (in USD), was sourced from the Factset database. For the purpose of research and analysis, this time period was subdivided into two, viz., (a) January 2004 to September 2008 (Pre-crisis period)and (b) October 2008 to December 2012 (Post-crisis period). September 2008 was chosen as the period of demarcation as the onset of economic slowdown started in this period, which saw the filing of bankruptcy by Lehman Brothers [14-16].

RQ1: What is the link between merchandise trade and investment flows on the basis of pre- and post-sub-prime crisis?

H1: There is positive correlation between the extent of integration of markets (via product trade flows) and investment flows from January 2004 to December 2012, w.r.t. India, USA and Europe. 
V1: Gamma-ness of trade and number of cross-border M\&A bids from January 2004 to September 2008 and October 2008 to December 2012.

RQ2: What are the spatial and temporal dimensions of investment flows?

H2: Within the aforementioned three geographical regions for the stated time period, the number of cross-border M\&As declined for the period October 2008 to December 2012, as compared to the period January 2004 to September 2008.

V2: The number of bids in the pre-and post-crisis period and comparison thereof.

\section{Regression model}

The Simple Linear Regression Model was done in this study, which is elucidated as under:

$\mathrm{Y}_{\mathrm{t}}=\alpha+\beta \mathrm{x}_{\mathrm{t}}$

Where $Y_{t}=$ number of $M \&$ A bids;

$\alpha=$ constant;

$\beta=$ slope and

$\mathrm{X}_{\mathrm{t}}=$ time dummy variable (coded as 1 from January 2004 to September 2008 and 0 from October 2008 to December 2012).

\section{Testing for equality of variances}

The $t$ test, for two samples, assuming equal and unequal variances, was done. It took the form of testing for acquirer being India and the targets being USA and Europe and vice-versa [17-19]. This was done for the pre-and post-crisis periods separately. Similarly, the F test was also performed, based on the above parameters.

\section{Empirical Research and Findings}

\section{Interpretation of gamma-ness of trade}

$\Upsilon_{\mathrm{ij}}$ between India and USA was 0.018 in 2004 and 0.0037 in 2012. This measure, in 2011 (0.0036) is approximately equal to that in 2008 (0.0035). In other words, it took the economies three years to reach the level of integration to pre-crisis levels. It has consistently increased over the period 2004-12, but for 2009, when it was 0.0026 , after declining by $26.6 \%$, when compared to 2008 . This shows that the Indian and US economies are more integrated now than the pre-crisis levels. $\Upsilon_{\mathrm{ij}}$ grew with the highest pace at $31.25 \%$ in 2008 .

$\Upsilon_{i \mathrm{ij}}$ between India and UK witnessed an increase over the period, except in the years 2006, 2009 and 2012, when it had declined. The year 2011 saw the highest growth rate of $35.04 \%$ for the period.

\section{Interpretation of results relating to hypotheses}

Result 1: The correlation coefficient between the number of crossborder M \& A bids and gamma-ness of trade was calculated. This was done for the periods 2004-08 and 2009-12 for the economies of India, USA and Western and Eastern Europe (UK) . The correlation matrix is given in Table 1 . As regards $\mathrm{H} 1$, there is low and negative correlation $(-0.14)$ for 2004-08 when the target was India and acquirer was USA. It is, however, significant at 0.68 for the period 2009-12. This depicts the greater degree of association between the said variables after the crisis. On the other hand, when USA was target and India was the acquirer, the correlation stands at 0.19 (2004-08) and 0.36 (2009-12).

When the target was India and the acquirer was Europe, the correlation coefficient increased from -0.25 (2004-08) to a very

\begin{tabular}{|c|c|c|c|}
\hline & $\mathbf{2 0 0 4 - 1 2}$ & $\mathbf{2 0 0 4 - 0 8}$ & $\mathbf{2 0 0 9 - 1 2}$ \\
\hline $\begin{array}{c}\text { India \& USA: } \\
\text { target- India, } \\
\text { acquirer-USA }\end{array}$ & 0.39 & Minus 0.14 & 0.68 \\
\hline $\begin{array}{c}\text { India \& USA: } \\
\text { target- USA, } \\
\text { acquirer-India }\end{array}$ & Minus 0.07 & 0.19 & 0.36 \\
\hline $\begin{array}{c}\text { India \& Europe/ } \\
\text { UK: target- India, } \\
\text { acquirer-Europe }\end{array}$ & 0.27 & Minus 0.25 & 0.84 \\
\hline $\begin{array}{c}\text { India \& Europe/ } \\
\text { UK: target -Europe, } \\
\text { acquirer-India }\end{array}$ & 0.34 & 0.47 & 0.68 \\
\hline
\end{tabular}

Table 1: Correlation matrix-Number of M\&A bids and gamma-ness of trade.

significant 0.84 (2009-12). This result, to an extent, mirrors that where the acquirer was USA and target was India, in the sense that it increased from a negative correlation in the pre-crisis period to a positive and significant number in the post-crisis period. When the target was Europe and acquirer was India, the correlation increased from 0.47 (2004-08) to 0.68 (2009-12).

Result 2: The number of cross-border M \& A bids (where the base equity value is given) was summed up for the period January 2004 to September 2008 and from October 2008 to December 2012. This was done for four cases, viz., where India was the target and acquirers were USA and Europe and vice-versa.

The number of M \& A bids increased only in the case of Indo-US M \& As, where India was the target for the period October 2008 to December 2012, as compared to the period January 2004 to September 2008. The number of such bids declined significantly in cases where India was the acquirer and USA and Europe were the targets. The number of cross-border deals, with India as the target and Europe being the acquirer, remained the same during the given period of time.

India is one of the important emerging markets and is part of the Brazil, Russia, India, China and South Africa (BRICS) grouping. Its economy has shown resilience in the midst of global meltdown. It has emerged as a target market for multitudinous mid-sized companies from the USA, since the time the latter has witnessed signs of revival. The nature and scope of deals is undergoing a shift. The Indian companies are looking for collaborative deals that involve minority stakes, Joint Ventures and earnouts, rather than majority stake-based acquisitions. For instance, the acquisition of McCamish Systems by Infosys Technologies and the merger of Sparta Consulting with KPIT Cummins are a case in point [20-23].

As regards the outbound deals by India are concerned, the strong capital market in the domestic sphere, coupled with relatively robust cash reserves are funding the deals. However, in the case of outbound deals to Europe, there has been a decline, attributable to reasons such as stressed balance sheets of companies and more expensive foreign assets, on account of depreciation in the Indian Rupee (INR) [24]. The lack of buoyancy in the economy led to fewer domestic deals in India in the year 2015 [25].

\section{Interpretation of regression results}

The $\mathrm{F}$ value is significant when the acquirer is India and the target is either USA or Europe. In other words, India is scouting for M \& A deals where there are opportunities, regardless of the target country. India is looking for good bargain by going global, thanks not merely to the liberal macro-economic policy regime, but also to the risk-taking appetite of Indian companies. 
Citation: Balachandran BV, Lavanya CNM (2016) Mergers and Acquisitions and Trade Integration: A Spatial and Temporal Study of India. J Glob Econ 4: 192. doi:10.4172/2375-4389.1000192

Page 4 of 6

\section{Interpretation of $\mathrm{t}$ and $\mathrm{F}$ tests}

The $t$ test for two sample assuming unequal and equal variances was significant only in the case of target being India and the acquirer being USA or Europe, in the pre-crisis period. The $t$ test shows no statistical significance in the other cases, notwithstanding the value of mega-deals such as Tata Steel's acquisition of Corus and Tata Motors' acquisition of Jaguar Land Rover. The F Test was not significant. Tables 2 and 3 give the details of the results of $\mathrm{t}$ and $\mathrm{F}$ tests respectively.

\section{Conclusion}

The decline in the measure of gamma-ness of trade, in this study, for both Indo-US and Indo-UK in 2009 is indicative of the ripple effect of the sub-prime crisis on trade integration. The results of correlation, between the number of $\mathrm{M} \& \mathrm{~A}$ bids and gamma-ness of trade, are a pointer to the fact that the period 2009-12 has seen a significant increase in correlation, as compared to 2004-08, regardless of whether India was the target or acquirer, vis-à-vis USA and Europe. These conclusions

\begin{tabular}{|c|c|c|c|c|c|}
\hline $\begin{array}{l}\text { T test: Two-Sample } \\
\text { assuming equal variance }\end{array}$ & & & & & \\
\hline \multirow[t]{2}{*}{ Jan 2004 to Sept 2008} & & & Oct 2008 to Dec 2012 & & \\
\hline & $\begin{array}{l}\text { Annual Average: target- } \\
\text { USA, acquirer- India }\end{array}$ & $\begin{array}{l}\text { Annual Average: target- } \\
\text { Europe, acquirer-India }\end{array}$ & & $\begin{array}{l}\text { Annual Average: target- } \\
\text { USA, acquirer- India }\end{array}$ & $\begin{array}{l}\text { Annual Average: target- } \\
\text { Europe, acquirer-India }\end{array}$ \\
\hline Mean & 161.64 & 140.42 & Mean & 570.96 & 176.40 \\
\hline Variance & 16359.04 & 16003.83 & Variance & 742949.8 & 23446.72 \\
\hline Observations & 5 & 5 & Observations & 5 & 5 \\
\hline Pooled variance & 16181.44 & & Pooled variance & 383198.3 & \\
\hline $\begin{array}{l}\text { Hypothesized Mean } \\
\text { Difference }\end{array}$ & 0 & & $\begin{array}{l}\text { Hypothesized Mean } \\
\text { Difference }\end{array}$ & 0 & \\
\hline Df & 8 & & $\mathrm{Df}$ & 8 & \\
\hline t Stat & 0.26 & & t Stat & 1.01 & \\
\hline $\mathrm{P}(\mathrm{T}<=\mathrm{t})$ one-tail & 0.40 & & $\mathrm{P}(\mathrm{T}<=\mathrm{t})$ one-tail & 0.17 & \\
\hline t critical one-tail & 1.86 & & t critical one-tail & 1.86 & \\
\hline $\mathrm{P}(\mathrm{T}<=\mathrm{t})$ two-tail & 0.80 & & $\mathrm{P}(\mathrm{T}<=\mathrm{t})$ two-tail & 0.34 & \\
\hline \multirow[t]{2}{*}{ t critical two-tail } & 2.31 & & $\mathrm{t}$ critical two-tail & 2.31 & \\
\hline & $\begin{array}{c}\text { Annual Average: target- } \\
\text { India, acquirer-USA }\end{array}$ & $\begin{array}{l}\text { Annual Average: target- } \\
\text { India, acquirer-Europe }\end{array}$ & & $\begin{array}{l}\text { Annual Average: target- } \\
\text { India, acquirer-USA }\end{array}$ & $\begin{array}{l}\text { Annual Average: target- } \\
\text { India, acquirer-Europe }\end{array}$ \\
\hline Mean & 58.42 & 32.21 & Mean & 156.29 & 58.87 \\
\hline Variance & 466.47 & 248.12 & Variance & 13729.73 & 1667.23 \\
\hline Observations & 5 & 5 & Observations & 5 & 5 \\
\hline Pooled variance & 357.29 & & Pooled variance & 7698.48 & \\
\hline $\begin{array}{l}\text { Hypothesized Mean } \\
\text { Difference }\end{array}$ & 0 & & $\begin{array}{l}\text { Hypothesized Mean } \\
\text { Difference }\end{array}$ & 0 & \\
\hline Df & 8 & & Df & 8 & \\
\hline t Stat & 2.19 & & t Stat & 1.76 & \\
\hline $\mathrm{P}(\mathrm{T}<=\mathrm{t})$ one-tail & 0.03 & & $\mathrm{P}(\mathrm{T}<=\mathrm{t})$ one-tail & 0.06 & \\
\hline $\mathrm{t}$ critical one-tail & 1.86 & & $\mathrm{t}$ critical one-tail & 1.86 & \\
\hline $\mathrm{P}(\mathrm{T}<=\mathrm{t})$ two-tail & 0.06 & & $\mathrm{P}(\mathrm{T}<=\mathrm{t})$ two-tail & 0.12 & \\
\hline $\mathrm{t}$ critical two-tail & 2.31 & & t critical two-tail & 2.31 & \\
\hline \multicolumn{6}{|l|}{$\begin{array}{l}\text { t-Test: Two-Sample } \\
\text { assuming unequal } \\
\text { variances }\end{array}$} \\
\hline \multirow[t]{2}{*}{ Jan 2004 to Sept 2008} & & & Oct 2008 to Dec 2012 & & \\
\hline & $\begin{array}{l}\text { Annual Average: Target- } \\
\text { USA, acquirer-India }\end{array}$ & $\begin{array}{l}\text { Annual Average: target- } \\
\text { Europe, acquirer-India }\end{array}$ & & $\begin{array}{l}\text { Annual Average: Target- } \\
\text { USA, acquirer-India }\end{array}$ & $\begin{array}{l}\text { Annual Average: target- } \\
\text { Europe, acquirer-India }\end{array}$ \\
\hline Mean & 161.64 & 140.42 & Mean & 570.96 & 176.40 \\
\hline Variance & 16359.04 & 16003.83 & Variance & 742949.8 & 23446.72 \\
\hline Observations & 5 & 5 & Observations & 5 & 5 \\
\hline $\begin{array}{l}\text { Hypothesized Mean } \\
\text { difference }\end{array}$ & 0 & & $\begin{array}{l}\text { Hypothesized Mean } \\
\text { difference }\end{array}$ & 0 & \\
\hline Df & 8 & & Df & 4 & \\
\hline t Stat & 0.26 & & t Stat & 1.01 & \\
\hline $\mathrm{P}(\mathrm{T}<=\mathrm{t})$ one-tail & 0.40 & & $\mathrm{P}(\mathrm{T}<=\mathrm{t})$ one-tail & 0.19 & \\
\hline t critical one-tail & 1.86 & & t critical one-tail & 2.13 & \\
\hline $\mathrm{P}(\mathrm{T}<=\mathrm{t})$ two-tail & 0.80 & & $\mathrm{P}(\mathrm{T}<=\mathrm{t})$ two-tail & 0.37 & \\
\hline t critical two-tail & 2.31 & & t critical two-tail & 2.78 & \\
\hline
\end{tabular}


Citation: Balachandran BV, Lavanya CNM (2016) Mergers and Acquisitions and Trade Integration: A Spatial and Temporal Study of India. J Glob Econ 4: 192. doi:10.4172/2375-4389.1000192

Page 5 of 6

\begin{tabular}{|c|c|c|c|c|c|}
\hline & $\begin{array}{c}\text { Annual Average: target- } \\
\text { India, acquirer-USA }\end{array}$ & $\begin{array}{l}\text { Annual Average: target- } \\
\text { India, acquirer- Europe }\end{array}$ & & $\begin{array}{c}\text { Annual Average: target- } \\
\text { India, acquirer-USA }\end{array}$ & $\begin{array}{l}\text { Annual Average: target- } \\
\text { India, acquirer- Europe }\end{array}$ \\
\hline Mean & 58.42 & 32.21 & Mean & 156.29 & 58.87 \\
\hline Variance & 466.47 & 248.12 & Variance & 13729.73 & 1667.23 \\
\hline Observations & 5 & 5 & Observations & 5 & 5 \\
\hline $\begin{array}{l}\text { Hypothesized Mean } \\
\text { Difference }\end{array}$ & 0 & & $\begin{array}{l}\text { Hypothesized Mean } \\
\text { Difference }\end{array}$ & 0 & \\
\hline Df & 7 & & Df & 5 & \\
\hline t Stat & 2.19 & & t Stat & 1.76 & \\
\hline $\mathrm{P}(\mathrm{T}<=\mathrm{t})$ one-tail & 0.03 & & $\mathrm{P}(\mathrm{T}<=\mathrm{t})$ one-tail & 0.07 & \\
\hline t critical one-tail & 1.89 & & $\mathrm{t}$ critical one-tail & 2.02 & \\
\hline $\mathrm{P}(\mathrm{T}<=\mathrm{t})$ two-tail & 0.06 & & $\mathrm{P}(\mathrm{T}<=\mathrm{t})$ two-tail & 0.14 & \\
\hline t critical two-tail & 2.36 & & t critical two-tail & 2.57 & \\
\hline
\end{tabular}

Table 2: Results of $t$ test.

\begin{tabular}{|c|c|c|}
\hline F test & $\begin{array}{c}\text { Target-USA, Europe, } \\
\text { Acquirer-India }\end{array}$ & $\begin{array}{c}\text { Target-India, Acquirer- } \\
\text { USA, Europe }\end{array}$ \\
\hline Jan '04 to Sept '08 & 0.2866 & 0.0005 \\
\hline Oct '08 to Dec '12 & 0.0000 & 0.0002 \\
\hline
\end{tabular}

Table 3: Results of $\mathrm{F}$ test.

are corroborated by the DHL Global Connectedness Index (GCI) 2014 (which tracks the flows of trade, capital, information and people and their associated depth and breadth of 140 countries). Per this index, the global connectedness deepened in 2013, after a stalled recovery in 2012. It witnessed a drop in the immediate period subsequent to crisis period, implying that the level of globalization declined, as compared to that in 2007 [26].

There was a rise in the number of Indo-US M \& A bids with India being the target in the post-crisis period. However, where the acquirer was India and the targets were USA and Europe, there was a significant reduction in the number of such bids. In the scenario of the acquirer being Europe and target being India, there was no change in the number of such deals. The aforementioned results encapsulate the 'period effects' of M \& A bids, while mapping them with the extent of trade integration. This paper is thus uniquely placed in terms of its contribution to international business literature.

As trade integration increases the likelihood of a Merger \& Acquisition [27], the former should be strengthened via the mechanism of Free Trade Agreements (FTA), or the more inclusive Comprehensive Economic Partnership Agreements (CEPA) between India and USA as well as with Europe. This, when paired with a sanguine business environment, would lead to a higher number of M\&A deals in the said regions. The easing of FDI norms, coupled with the anticipated changes in the Indian regulatory sphere such as the bankruptcy law, are slated to go a long way in improving the ease of doing business in India and culminate in increased $\mathrm{M} \& \mathrm{~A}$ activity.

\section{Scope for Future Research}

This paper has been written focusing primarily on the macro level. The reach can be enlarged by including the meso and micro units of analysis as well. Given the relatively higher risk and return profile of $\mathrm{M}$ \& As when compared to greenfield investment, the success or otherwise of the multitudinous mega-deals hinges on a variety of factors, which may be studied in detail in the future. The impact of diversification (conglomerate vis-à-vis concentric) on the number of cross-border $\mathrm{M}$ \& A bids provides scope for further research. Furthermore, the sectoral influence (IT/ITES or otherwise) and the existence of Golden Parachute in the $\mathrm{M} \& \mathrm{~A}$ deals, also provide avenues for research in the future.

\section{References}

1. Contractor FJ, Kumar V, Kundu S, Pedersen T (2010) Reconceptualizing the firm in a world of outsourcing and offshoring: The organizational and geographical relocation of high-value company functions. Journal of Management Studies 47: 1417-1433

2. Bertrand O, Zitouna $\mathrm{H}$ (2006) Trade liberalization and industrial restructuring The role of cross-border Mergers and Acquisitions. Journal of Economics and Management Strategy 15: 479-515.

3. Ray S, Gubbi SR (2009) International acquisitions by Indian firms: Implications for research on Emerging Multinationals. The Indian Journal of Industrial Relations 45: 11-26.

4. Li J, Li Y, Shapiro D (2012) Knowledge seeking and outward FDI of emerging market firms: The moderating effect of inward FDI. Global Strategy Journal 2: 277-295.

5. Ramamurti R (2012) What is really different about emerging market multinationals? Global Strategy Journal 2: 41-47.

6. Singal A, Jain AK (2012) Outward FDI trends from India: Emerging MNCs and strategic issues. International Journal of Emerging Markets 7: 443-456.

7. Agnihotri A (2013) Determinants of acquisitions: An Indian perspective Management Research Review 36: 882-898.

8. Contractor FJ (2013) Punching above their weight: The sources of competitive advantage for emerging market multinationals. International Journal of Emerging Markets 8: 1-25.

9. http://databank.worldbank.org/data/views/reports/tableview.aspx?isshared=tru e\&ispopular=country\&pid=3

10. http://www.ghemawat.com/Blog/post/2013/01/30/World-Less-GlobalizedToday-than-in-2007-DHL-Global-Connectedness-Index-2012.aspx

11. http://gtw3.grantthornton.in/assets/Grant_Thornton_Dealtracker_Annual_ edition_2013.pdf

12. http://www.intracen.org/trade-support/trade-statistics/

13. http://www.intracen.org/exporters/statistics-export-country-product/

14. http://www.trademap.org/tradestat/Bilateral_TS.aspx

15. http://www.publications.parliament.uk/pa/cm200506/cmselect/ cmtrdind/881/881i.pdf

16. http://www.icrier.org/pdf/Background\%20Note.pdf

17. https://www.gov.uk/government/uploads/system/uploads/attachment_data/ file/43313/11-720-uk-trade-performance.pdf

18. http://www.dgciskol.nic.in/annualreport/book_3e.pdf

19. http://rbidocs.rbi.org.in/rdocs/Bulletin/PDFs/01AIFTE120912.pdf

20. http://economictimes.indiatimes.com/magazines/companies/infosys-acquiresmccamish-systems-to-strengthen-end-to-end-solutions/articleshow/5231516.cms

21. http://www.kpit.com/downloads/press-releases/pr-sparta-consulting-to-mergewith-kpit-cummins-oct-30-2009.pdf 
Citation: Balachandran BV, Lavanya CNM (2016) Mergers and Acquisitions and Trade Integration: A Spatial and Temporal Study of India. J Glob Econ 4: 192. doi:10.4172/2375-4389.1000192

Page 6 of 6

22. http://www.vccircle.com/news/general/2010/04/23/\%C2\%91india-readysustainable-outbound-deal-making-trend $\% \mathrm{C} 2 \% 92$

23. http://www.kpit.com/downloads/press-releases/pr-sparta-consulting-to-mergewith-kpit-cummins-oct-30-2009.pdf

24. http://www.avendus.com/Upload/NewsLetter/Gateway_to_Indo_ European_M\&A_February_2014.pdf
25. http://articles.economictimes.indiatimes.com/2015-12-25/news/69300489_1_ deal-value-deals-worth-inbound-deals

26. http://www.dhl.com/en/about_us/logistics_insights/studies_research/global_ connectedness_index/global_connectedness_index.html\#.VtWdZPI97IV

27. Horn H, Persson L (2001) The equilibrium ownership of an international oligopoly. Journal of International Economics 53: 307-333. 